Wiesław Ratajczak

Instytut Filologii Polskiej, Uniwersytet im. Adama Mickiewicza w Poznaniu

\title{
O potrzebie wierności drobiazgom
}

Wydanie książki Moniki Piątkowskiej [2017] Prus. Śledztwo biograficzne wywołało nadzwyczajną falę zainteresowania osobą i dziełem wybitnego powieściopisarza. Ukazały się liczne wywiady z autorką, prasowe recenzje i omówienia, niezliczone komentarze internetowe, a fragmenty książki czytane były w prestiżowej rozgłośni: Programie Drugim Polskiego Radia. Recepcja nowej biografii Aleksandra Głowackiego osiągnęła więc skalę i formy raczej niespotykane w przypadku książek poświęconych piśmiennictwu minionych wieków. Wobec przeważających ocen pozytywnych, a niejednokrotnie wręcz entuzjastycznych, mniejszość stanowiły opinie historyków literatury. Wady książki wskazała m.in. Agnieszka Bąbel [2018], autorka obszernego omówienia zamieszczonego w „Tygodniku Powszechnym”. Stanowczy sprzeciw recenzentki wzbudziła już główna teza Piątkowskiej [2017: 18]: "Jako dorosły pisarz Aleksander czerpał materiał literacki niemal wyłącznie ze swojej biografii”. Wyszedłszy z tego założenia, autorka biografii potraktowała twórczość Prusa (skądinąd konsekwentnie przywoływanego z imienia, co zapewne miało skrócić dystans między czytelnikiem książki a jej bohaterem) jako swoistą, zakamu- 
flowaną kronikę życia pisarza i jego bliskich. Metoda tytułowego śledztwa polegała na tym, by zachowania bohaterów powieści i opowiadań odczytać jako zapisy przeżyć, fobii, sekretów Prusa. $\mathrm{W}$ istocie - wymiar psychologiczny tej prozy jest oryginalny i intrygujący, od dawna też wzbudzał zainteresowanie wielu czytelników, w tym badaczy literatury. Warto jednak podkreślić, jak to zrobiła Bąbel [2018], że autor Lalki był doskonale zorientowany we współczesnych mu teoriach psychologicznych, a

już pobieżne przejrzenie katalogu jego księgozbioru [...] ujawnia, że na półkach w mieszkaniu Głowackich stało około 90 pozycji z dziedziny psychologii, zbieranych od lat 70. XIX w., począwszy od popularnych poradników dotyczących ćwiczenia pamięci czy opanowania nieśmiałości, po solidne dzieła encyklopedyczne.

Nawet więc jeśli pisarz korzystał z przeżyć własnych i obserwacji zachowania rodziny, przyjaciół i znajomych (czemu zaprzeczać nie ma sensu), to niejako modelował je, posługując się współczesnymi ustaleniami naukowymi. Świadomość metod dotyczyła oczywiście nie tylko psychologii, ale także - o czym przypomniała recenzentka - spraw warsztatu literackiego, co trudno przeoczyć, mając do dyspozycji choćby potężny tom Literackich notatek o kompozycji opracowanych przez Annę Martuszewską [Prus 2010]. To, w jaki sposób pisarz w procesie twórczym spożytkowywał swą wiedzę (nie tylko) psychologiczną, a ogólną refleksję o zasadach tworzenia dzieła przekładał na jego konkret, historycy literatury od dawna starają się precyzyjnie ustalić, nie pomijając przy tym w dociekaniach interpretacyjnych także kwestii biograficznych. Relacja między, mówiąc najkrócej, dziełem a życiem jest w przypadku wybitnej literatury zawsze skomplikowana. Tymczasem autorka najnowszej biografii Prusa przygotowała zdumiewające w swej prostocie perpetuum mobile: gdy nie znamy jakiegoś szczegółu z życia pisarza, odpowiedź pozwoli nam znaleźć domysł wynikający z lektury powieści lub noweli, a gdy czegoś nie rozumiemy w dziele - zawsze można się odwołać do domniemań natury biograficzno-psychologicznej. 
Metoda Piątkowskiej nie polega na eksploracji źródeł archiwalnych, do udokumentowanej wiedzy o kolejach życia Głowackiego nie dodała żadnego nowego szczegółu. Czytelnikowi, który wyżej ceni sobie fakty od domysłów, lektura Śledztwa... nie zapewni poznawczej satysfakcji, co najwyżej stworzy mu okazję do rozpoznawania inspiracji zaczerpniętych (i najczęściej nieodnotowanych w przypisach...) z wcześniejszych opracowań oraz konstatowania luk w bibliografii. Być może więc warto uznać tę książkę za źródło ciekawych sugestii interpretacyjnych, pozwalających na nowo, dzięki kluczowi biograficznemu, odczytać najważniejsze pozycje w dorobku pisarza?

Z tego punktu widzenia szczególne zainteresowanie siłą rzeczy wzbudzić musi rozdział książki zatytułowany Sława i poświęcony Lalce. Rekonstrukcję genezy arcypowieści rozpoczęła Piątkowska od sprawy przenosin Prusa do „Kuriera Codziennego”. Trzeba przyznać, że to perspektywa dość intrygująca, gdyż pozwala m.in. na odczytanie nowej powieści w kontekście literackiego agonu, podjętej przez pisarza próby przetasowania środowiskowych relacji i zapewnienia sobie nowej pozycji w świecie literackim. Niestety, ta szansa nie została w pełni wykorzystana, a w swych odczytaniach podążyła autorka książki duktem wyznaczonym już przez pierwszych, niechętnych Prusowi recenzentów. Ich stanowisko sprowadzić można do supozycji, że Lalka powstawała bez uprzedniego planu i bez gruntownych przygotowań. Piątkowska [2017: 312] stwierdziła autorytatywnie: „Zapewnieniom Aleksandra, jakoby do Lalki długo zbierał materiały, przeczy też sama powieść. Jak w lustrze odbiło się w niej wiele wcześniejszych utworów Aleksandra”. Nasuwa się pytanie, dlaczego nie można potraktować wcześniejszej twórczości właśnie jako rozpisanych na lata przygotowań dzieła (czy pierwszego ogniwa jego cyklu), jak sam autor wcześniej to ujął: „Z wielkich pytań naszej epoki” [Głowacki 1959: 120]? Sukces Ogniem i mieczem, własne już niemałe doświadczenie pisarskie i życiowe, pogłębiona znajomość realiów warszawskich - gdy te i inne kwestie wziąć pod uwagę, trudno nie przyjąć założenia, że Prus mógł podjąć decyzję o próbie stworzenia swoistej summy. Do jej realizacji zapewne nie podchodziłby bez całościowego planu, jak to zasugerowała Piątkowska. Z kolei 
fakt, że pisarz skorzystał ze swych wcześniejszych pomysłów literackich, bynajmniej jej tezy nie wzmacnia.

Przekonana o roli przypadku w procesie twórczym i o kształtowaniu się pomysłu na powieść podczas jej pisania Piątkowska [2017: 312] dodała:

Nie jest wykluczone, że zaczynając pisać swoją najsłynniejszą powieść, Aleksander miał w pierwszej chwili jakiś inny pomysł na poprowadzenie akcji, być może nawet jej głównym bohaterem miał być Ignacy Rzecki. Rozwiązanie takie sugeruje pierwsza scena, w której towarzystwo warszawskie plotkuje o Wokulskim i jego współpracowniku Rzeckim.

Sprawdźmy, w jakim stopniu prawdopodobna to teza. Owa pierwsza odsłona mieści się w rozdziale Jak wygląda firma J. Mincel i S. Wokulski przez szkło butelek?. Powieściowi rozmówcy bynajmniej nie plotkują w niej o Rzeckim, ba - wymieniają go ledwie raz, a mieli po temu niejedną okazję, choćby wtedy, gdy wspominali, że właściciel, wyjeżdżając na wojnę, „sklep zostawił na Opatrzności boskiej” [Prus 1998: 9]. Powieściowy Radca Węgrowicz, zachęcony przez ajenta handlowego Szprota, obszernie opowiadał o Wokulskim, o jego pracy u Hopfera i o edukacji w Szkole Przygotowawczej i Szkole Głównej. Aluzyjnie wspominał także zaangażowanie Wokulskiego w przedpowstaniową konspirację, zesłanie i powrót do Warszawy. Subiekt Ignacy w tej opowieści, ogarniającej trybem anegdoty całe dorosłe życie głównego bohatera, rolę ma nader ograniczoną, zamkniętą we wzmiance: „[...] nareszcie przy protekcji swego dzisiejszego dysponenta, Rzeckiego, wkręcił się do sklepu Minclowej” [Prus 1998: 18]. Czy to zdanie świadczy $\mathrm{w}$ jakimkolwiek stopniu o planach uczynienia $\mathrm{z}$ Ignacego protagonisty powieści? Biografia Wokulskiego, stronniczo, z uprzedzeniem przedstawiona przez rozmówców, miała rozbudzić ciekawość czytelnika, zwłaszcza że nakreślona została nader oryginalnie (wszak widziana jest przez, wspomniane w tytule rozdziału, szkło butelek). Złożyło się na ten swoisty biogram dużo szczegółów, m.in. wspomnienie pokoleniowego doświadczenia, jakim było powstanie, poprzedzające je wydarzenia i ich dotkliwe następstwa, 
wreszcie uwzględniono w nim najważniejszą dla polskiego życia intelektualnego instytucję, jaką była Szkoła Główna. A wszystko to $\mathrm{w}$ formie rodzajowego, dowcipnego obrazka. Owszem, już po zamknięciu pierwszego odcinka Prus dodał pointę poświęconą Rzeckiemu:

Ani jednak ciekawość ogółu, ani fizyczne i duchowe zalety trzech subiektów, ani nawet ustalona reputacja sklepu może nie uchroniłaby go od upadku, gdyby nie zawiadował nim czterdziestoletni pracownik firmy, przyjaciel i zastępca Wokulskiego, pan Ignacy Rzecki. [Prus 1998: 20].

Wprawdzie to jemu poświęcony został następny rozdział, ale taką decyzję pisarza można uznać nie za wyraz wahania co do wyboru głównego bohatera, ale świadomej retardacji, gry z czytelniczym oczekiwaniem na pojawienie się Wokulskiego. Z kolei Rzecki, tak powołany, nie rywalizuje z nim o miano protagonisty Lalki, ale staje się głównym bohaterem powieści w powieści, czyli Pamiętnika starego subiekta. Nazwanie go przez Piątkowską [2017: 212] „kronikarzem przyjaciela" też nie pozwala uchwycić istoty rzeczy, bo zapewne większa część Pamiętnika... w ogóle nie dotyczy Wokulskiego.

Piszę o sprawach oczywistych dla każdego uważnego czytelnika powieści. Pragnę w ten sposób podkreślić, jak bardzo ryzykowne są wobec Lalki wszelkie formuly uogólniające, jak łatwo je podważyć, sięgając po tekst. Od wierności w rzeczach małych zawsze zależy powodzenie filologa i biografa, ale wobec Prusa i jego dzieła wszelkie niewierności rażą szczególnie, bo swoją twórczość oparł na przekonaniu, że nie ma spraw, ludzi, miejsc, przedmiotów nieważnych.

Piątkowska konsekwentnie utrzymywała, że Prus tworzył fabulę na bieżąco, z odcinka na odcinek, czego efektem jest "najdoskonalsza wersja autobiografii Aleksandra" [Piątkowska 2017: 313]. Oryginalność tego wizerunku polegała na tym, że Prus przyjął postać portretu podwójnego: „Jest czymś prawdziwie niezwykłym, jak precyzyjnie i głęboko Aleksander rozgraniczył w powieści swoje dwa oblicza, dając życie dwóm niezależnym bohaterom: Ignacemu Rzeckiemu i Stanisławowi Wokulskiemu” [Piątkowska 
2017: 315]. To sugestia ciekawa, ale równie dobrze ową podwójność ująć można w tradycyjną, uniwersalną opozycję vita activa - vita contemplativa. Z kolei kiedy przyjrzymy się szczegółom fabularnym, schemat zastosowany przez biografkę zawodzi, bo Rzecki (reprezentujący jakoby „potulną, ugodową część Aleksandra” [Piątkowska 2017:316]) w pewnym momencie porzucił obowiązki, poszedł na wojnę i tułał się po Europie, a „mroczny i zbuntowany” [Piątkowska 2017: 317] Wokulski stał się na długo mieszczaninem przy boku żony, a po jej śmierci pogrążył się w letargu, przerwanym dopiero widokiem Izabeli w teatrze. W obu postawach jest wiele sprzeczności. Natomiast kiedy Piątkowska w swej analizie wyróżniła jako modelową scenę wydobywania się Stanisława z piwnicy, historykowi literatury mogło się zrobić żal, że nie wspomniała o poprzednikach, którzy wiele lat przed nią na ten fragment zwrócili uwagę i podobnie go odczytali. Jan Tomkowski [1993: 134-135] od tego obrazu rozpoczął przecież swą inspirowaną psychoanalizą refleksję o Wokulskim neurotycznym. Współczesna biografistka też prześledziła kompleksy bohatera Lalki, by dojść do następującego wniosku: Wokulski (jak Głowacki)

czuł się winny, że jest mężczyzną, że pożąda i pragnie kobiety, zamiast zajmować się interesami i budowaniem lepszego świata. Aby wyzwolić się z tego pragnienia i wrócić na swój wewnętrzny tor, musiał stoczyć walkę z sobą i z obiektem swojej miłości, zniszczyć go, po to, by się od niego uwolnić. [Piątkowska 2017: 318]

Formuła brzmi atrakcyjnie, nie trzeba jednak wielkiej wnikliwości, by dostrzec jej fałsz. Powrót na „wewnętrzny tor” oznaczać mógłby przecież nie zajmowanie się interesami i ulepszaniem świata, lecz recydywę marazmu, lenistwa, rozczarowania i braku zainteresowania czymkolwiek poza własną, mieszczańską wygodą. Przypomnijmy: wszystko - powrót do fascynacji nauką, błyskotliwą karierę handlową, pomoc Wysockim i Magdalence... - Wokulski zawdzięczał przebudzeniu dzięki miłości i namiętności.

Powracając zaś do postaci subiekta, wypada podkopać kolejną apodyktyczną tezę Piątkowskiej [2017: 165]: 
Tworząc postać Rzeckiego, Aleksander nie oparł się na żadnym ze swoich przyjació - stary subiekt, towarzysz Wokulskiego, jak wiele na to wskazuje, został ulepiony z jego własnych doświadczeń i stanowił psychiczne dopełnienie Wokulskiego: był tą częścią osobowości, którą Aleksander najczęściej pokazywał światu.

A gdyby tak zajrzeć do książki Ludwika Grzeniewskiego (kolejny nieobecny w indeksie i bibliografii) Warszawa w "Lalce” Prusa i przeczytać odpowiedni fragment o Bolesławie Morskim, pierwowzorze Rzeckiego, cytowane zdanie musiałoby zostać sformułowane w mniej autorytatywnym tonie. Ów Morski pracował w sklepie winno-kolonialnym Nowickiego przy ulicy Miodowej 3, a do tego autentycznego sklepu zaszedł w powieści Prusa nie kto inny jak właśnie Ignacy [Grzeniewski 1965: 164-166]. Jeśli autorka zajrzałaby jeszcze do książki Jakuba Malika „Lalka”. Historie z różnych światów (też pominiętej w przypisach), dowiedziałaby się, że Antoni Trautwein, jeden z subiektów lubelskiego sklepu Jana Mincla, „odpowiadałby w najbardziej ogólnych zarysach osobowości Ignacego Rzeckiego" [Malik 2005: 68]. Oczywiście można z tymi tropami polemizować, ale nie można ich przemilczać.

Po upraszczającym ujęciu psychologicznej warstwy Lalki przez Piątkowską [2017: 347] jej uwagi o kolejnych powieściach Prusa już nie mogly zaskoczyć. Również Ramzes XIII z Faraona okazal się, naturalnie, kolejnym autoportretem:

On sam, ukryty w postaci młodego władcy, pozostawał w nim jednak dawnym sobą: namiętny, gniewny, pełen sprzeczności, odrzucony przez bliskich, bity przez nauczycieli, skazany na przegraną i niedoświadczony faraon, „gwałtowny jak lew i uparty jak wól”, nosił w sobie wszystkie znane już z wcześniejszych utworów emocje i psychiczne rany Aleksandra.

Nowość, zdaniem autorki Śledztwa..., polegała na tym, że pisarz „dał upust uczuciom, które wcześniej krępował się ujawniać” [Piątkowska 2017: 347]. Owe tajone pragnienia Prusa tak streściła biografistka: 
Nie chciał być już kimś, kto musi walczyć o swoją pozycję lub kto uzyskuje ją dzięki talentom i przedsiębiorczości: w Faraonie Aleksander uczynił się władcą, księciem, człowiekiem, który już z racji urodzenia stoi wyżej od innych. [Piątkowska 2017:347]

Jak sprawdzić to przypuszczenie? Jak mu zaprzeczyć? Może, zamiast komentarza, wystarczy sparafrazować słynną piosenkę Tadeusza Chyły: „Faraon to ma klawe życie”? Tej mądrości fabuła powieści Prusa jednak nie potwierdza...

Zastanawiając się nad związkami Faraona z biografią jego twórcy, Piątkowska poruszyła atrakcyjną kwestię splotu erotyki i szaleństwa. Przy tej okazji postanowiła zaprezentować Prusa jako ekscentryka i dziwaka, posługując się osobliwym dowodem: „W jednej z anegdot [...] mówiono, że kupiwszy sobie maszynę do pisania, pisze na niej błahe polecenia dla żony i przekazuje jej przez służącą do drugiego pokoju" [Piątkowska 2017: 349]. Spróbujmy ten drobiazg (a od drobiazgów zależy wszystko) skomentować. Fascynację Prusa świeżym wówczas wynalazkiem opisała jedna ze współczesnych badaczek i przypomniała, że początek nauki „pisania na maszynie (a raczej, jak sam to określał, «zabawy») przypada na 13 grudnia 1897 rok” [Grabowska-Kuniczuk 2015: 240]. Faraona ukończył tymczasem 2 maja 1895 roku. Jakąż więc wartość dla interpretacji powieści ma rzekoma anegdota dotycząca zdarzeń o dwa lata późniejszych? Dalej: czy ta historyjka pozwala nazwać pisarza „skrajnym ekscentrykiem” [Piątkowska 2017: 349]? Przepraszam za trywialne porównanie, ale czy jeśli dziś ktoś wypróbowuje nowy smatrfon, wysyłając SMS żonie z biblioteki do salonu, potwierdza, że jest dziwakiem? Prus uczył się pisać, ale też bawił się i cieszył wynalazkiem; jako wprawki traktowal fikcyjne listy do żony i do Juliana Adolfa Święcickiego. Może warto przypomnieć, że jednym z pierwszych tekstów napisanych przez Prusa na maszynie była modlitwa Ojcze nasz? Życiowe drobiazgi niewątpliwie świadczą o osobowości artysty, ale zwłaszcza, gdy spoglądać na nie ze stuletniej ponad perspektywy, ostrożność w wyciąganiu wniosków jest bardzo wskazana. 
O tym, jak można połączyć z pożytkiem biograficzny szczegół z genezą utworu literackiego, przekonuje np. dawne studium Edwarda Pieścikowskiego [2012] o Omyłce. Tym ważnym opowiadaniem Prusa zajęła się również Piątkowska. Rozpoczęła od opinii pisarza o Szkicach weglem Henryka Sienkiewicza i od sprawy sukcesu finansowego swojego wielkiego współzawodnika. „Życie w cieniu wielkiego konkurenta" [Piątkowska 2017: 289] prowokowało do konkurencji i z tej właśnie pisarskiej rywalizacji wyprowadziła autorka genezę opowiadania Omyłka. Prusa spotkała klęska: „[...] nowela, która mogła być odpowiedzią na Sienkiewiczowskie Ogniem i mieczem" [Piątkowska 2017: 293], pozostała niemal niezauważona. Warto tę tezę wziąć pod uwagę, ale czy nie trzeba jej zestawić z rekonstrukcją genezy powieści przedstawioną przed laty we wspomnianym szkicu Pieścikowskiego? Badacz przypomniał napaść studentów, którzy ówczesnemu redaktorowi „Nowin” nie mogli darować krytycznych uwag o ich zachowaniu na prelekcji Włodzimierza Spasowicza o Polu, wygłoszonej 12 i 14 marca 1878 roku. Jak pisał Pieścikowski [2012: 66]:

Echa napaści z roku 1878 pobrzmiewają też $[\ldots]$ w Omytce, więc w utworze podejmującym z jednej strony problem inkwizytorskich praktyk „opinii publicznej”, egzemplifikowany drastycznym przykładem nieporozumień na tle narodowym, a z drugiej - problem krzywdy wyrządzonej uczciwej jednostce przez ludzi zaślepionych i nieodpowiedzialnych.

Do tropu autobiograficznego dodał badacz jeszcze wzmiankę o Józefie Ignacym Kraszewskim, którego w 1884 roku władze pruskie oskarżyły o szpiegostwo, a w prasie polskiej pojawily się wówczas głosy krytyczne wobec wielbionego dotąd pisarza. Czy sprowadzenie genezy powieści do zazdrości i rywalizacji między Prusem a Sienkiewiczem nie jest cofnięciem refleksji do czasu sprzed szkicu Pieścikowskiego? Nazwiska autora studium próżno szukać w indeksie i bibliografii, podobnie zresztą jak wielu innych prusologów.

Skoro Piątkowska w bohaterach powieści Prusa widzi autoportrety autora, to - półżartem - można zastanowić się, dlaczego 
pominęła Placówkę. Czy Józef Ślimak jest kreacją wyjątkową, autonomiczną? Niestety, biografistka ograniczyła się do rzekomych (bo przecież nieupublicznionych) reakcji Prusa na recenzje, a znalazłaby w tej powieści np. wdzięczny pretekst do refleksji o, wielekroć przez nią przypominanej, traumie Prusa związanej $\mathrm{z}$ agorafobią. Placówkę otwiera bowiem pełen rozmachu, śmiały, panoramiczny widok świata niejako z lotu ptaka.

Uogólnienie położyło się cieniem na wielu problemach w tej książce poruszanych. Na marginesie rzekomych dziwactw i szaleństw (pisarza i fikcyjnego Ramzesa XIII) pojawiła się w niej wzmianka na temat stosunku Stefana Żeromskiego do Prusa: „Swoją teorię na temat Aleksandra miał także Stefan Żeromski; w jego pojęciu był on po prostu człowiekiem zakłamanym i nieszczerym" [Piątkowska 2017: 349]. Czytelnik otrzymał więc wiadomość zwięzłą i konkretną: autor Ludzi bezdomnych miał autora Lalki za kabotyna. Temat ciekawych i skomplikowanych relacji obu pisarzy ma obszerną literaturę przedmiotu, wystarczy się odnieść do nie tak dawno wydanej rozprawy Zdzisława Jerzego Adamczyka. Badacz zauważał: „Literackich sukcesów męża pani Oktawii Prus nie doceniał, protekcjonalny zaś stosunek autora Lalki do Żeromskiego był dlań z pewnością trudny do przełknięcia” [Adamczyk 2013: 202]. Młodszy pisarz był tym lekceważeniem zirytowany, ale też przypomnieć warto, że z podziwem pisał w Dzienniku o humorze Prusa, a w tomie Wspomnień o Bolestawie Prusie cytowane są takie osobiste zapiski: „Włosy siwiejące, futro rozpięte, wielkie kalosze zabłocone po literacku. Niepozorna taka kreaturka - a to Prus, ten wielki psycholog ludu, ten optymista i satyryk nasz”, „Pisze tak cudowne rzeczy” [Żeromski 1962: 133]. W relacjach między wielkimi pisarzami nic nie jest „po prostu”.

W finale książki Piątkowska skoncentrowała uwagę czytelników na kwestii rzekomego późnego, pozamałżeńskiego ojcostwa Aleksandra Głowackiego. Historię związku pisarza z Aliną Sacewicz (która samotnie wychowywała Jana Bogusza, przedstawianego przez nią jako dziecko zmarłych polskich zesłańców) przed laty nagłośniła pisarka Gabriela Pauszer-Klonowska [1962]. Współczesna biografistka, przyjąwszy tę wersję, starała się ją uprawdopodobnić, czasami w sposób dość humorystyczny. Otóż 
powołała na świadka Vladimirasa Sakasa-Sakavičiusa, wówczas (w 1909 roku) gimnazjalistę i wielbiciela twórczości Prusa, w przyszłości litewskiego literata i pedagoga. Bez zapowiedzi odwiedził on pisarza w mieszkaniu przy ulicy Wilczej 12 i wspominał później, że w domu Głowackich panowała ponura atmosfera, pani Oktawia była zamknięta w sobie itd. Piątkowska obszernie te wrażenia młodzieńca za Pauszer-Klonowską przytoczyła, nie zadając sobie pytania, jak miał się zachować pisarz, którego nachodził młodociany wielbiciel talentu. Pointuje biografistka ten fragment w sposób tyleż spodziewany, ileż komiczny: „Nie jest wykluczone, że jednym z powodów, dla których w domu Głowackich panowała wówczas taka smutna atmosfera, była relacja Aleksandra z Aliną Sacewicz" [Piątkowska 2017: 443].

Czytając biografię pióra Piątkowskiej, można by pomyśleć, że Prus, skoncentrowany na swych traumach, fobiach i dziwactwach, niewiele czytał, z rzadka chodził na wystawy, nie bywał w operze. Biografia twórcy, inteligenta powinna uwzględniać to, że poza życiem uczuciowym swe aspiracje i dążenia realizował także na polu umysłowym. Jeśli nie wierzyć Piątkowskiej, że Lalka jest powieścią w zasadzie autobiograficzną, z Głowackim rozpisanym na Wokulskiego i Rzeckiego, to wtedy warto byłoby ją zobaczyć np. w kontekście Dickensowskim, o czym niedawno przekonująco pisała Aleksandra Budrewicz [2015: 210-213]. Tymczasem angielski pisarz pojawił się w książce ledwie dwa razy: przy okazji roku 1874 (gdy pisana wówczas Wigilia Prusa okazuje się „mocno inspirowana stylem Karola Dickensa i oparta na pomyśle jego Opowieści wigilijnej" [Piątkowska 2017: 207]) oraz w cytacie z notesu pisarza: „W mym sercu ścichnąć nie może Dickens” [Piątkowska 2017: 446]). Jakże kapitalny to cytat, niepozwalający zapomnieć, że nawet w prywatnych zapiskach swoje emocje pisarz przepuszczał przez pryzmat wielkiej literatury. Odnosząc się do kontekstu piśmiennictwa polskiego, można natomiast zapytać, czy jest w tej biografii obecny Prus jako czytelnik Adama Mickiewicza, autor bardzo ciekawego studium o Farysie? Niestety nie, Mickiewicz pojawia się tylko czterokrotnie przy okazji sporów o pomnik, a także w cytacie z Jana Kotta poświęconym rozprawie $\mathrm{z}$ romantyzmem. Można jedynie retorycznie zapytać, czy fakt (nie 
przypuszczenie, nie plotka) lektury wierszy najwybitniejszego z poetów nie powinien zostać uwzględniony w biografii pisarza?

Wydanie Śledztwa... to może dobry pretekst do „powtórki z Prusa”, do przypomnienia bogatej i niezwykle różnorodnej recepcji jego dzieła. Znajomość ustaleń historyków literatury nie musiała autorce przeszkadzać w jej prywatnym śledztwie, przeciwnie - ochroniłaby ją przed uproszczeniami i aprioryzmem. Po tej, rozczarowującej pod wieloma względami, lekturze nasuwa się pytanie, czy dziś może powstać książka o biografii Prusa? Śledztwo... wywołuje wręcz pilną potrzebę podjęcia takiej pracy. Nie tylko ze względu na braki tej książki, lecz także ze względu na prawdopodobieństwo utrwalenia upraszczających stereotypów dotyczących twórczości autora Lalki. Również dlatego, że - przy wszystkich wątpliwościach, jakie to studium budzi - stanowi ono kolejną zachętę do, jak to przed laty wyraził Tadeusz Boy-Żeleński, zdekonspirowania Prusa, pisarza bez biografii [Żeleński 1956: 194]. Zresztą artykuł Boya-Żeleńskiego z „Wiadomości Literackich” zacytowała Piątkowska, gdy chciała podkreślić, że Prus, jak nikt przed nim, potrafił pokazać kobietę luksusową. Wydaje się także, że autor Brązowników patronuje nowej biografii Prusa.

Każda książka biograficzna (a o Prusie zwłaszcza) skupiać musi się na detalach, życiowych drobiazgach. Autor Lalki szczegóły życia traktował w swej twórczości z wyjątkowym pietyzmem i odpowiedzialnością. Warto go naśladować, pisząc o jego życiu.

\section{Bibliografia}

Adamczyk Zdzisław Jerzy (2013), Jeszcze raz o Prusie i Żeromskim: czego nie wydrukowat Pigoń, „Pamiętnik Literacki”, R. CIV, z. 3, s. 199-203.

Bąbel Agnieszka (2018), Przygwożdżenie wiewiórem, „Tygodnik Powszechny", nr 4, [online], [dostęp 21 maja 2019], https://www. tygodnikpowszechny.pl/przygwozdzenie-wiewiorem-151621.

Budrewicz Aleksandra (2015), Dickens w Polsce. Pierwsze stulecie, Wydawnictwo Naukowe UP, Kraków.

Głowacki Aleksander (1959), Listy, oprac., komentarz, posł. Krystyna Tokarzówna, red. nauk. Zygmunt Szweykowski, PIw, Warszawa.

Grabowska-Kuniczuk Agata (2015), Bolestawa Prusa „zabawa” w pisanie na maszynie - narzędzie, autor, tekst, „Napis”, R. XXI, s. 235-249. 
Grzeniewski Ludwik (1965), Warszawa w „Lalce” Prusa, PIW, Warszawa.

Malik Jakub (2005), „Lalka”. Historie z różnych światów, Wydawnictwo KUL, Lublin.

Pauszer-Klonowska Gabriela (1962), Ostatnia miłość w życiu Bolesława Prusa, PIw, Warszawa.

Piątkowska Monika (2017), Prus. Śledztwo biograficzne, Znak, Kraków.

Pieścikowski Edward (2012), Geneza „Omyłki”, w: tegoż, Bolesław Prus humorysta w wielkim stylu, Wydawnictwo Poznańskie, Poznań, s. 57-70.

Prus Bolesław [właśc. Głowacki Aleksander] (1998), Lalka, oprac. Józef Bachórz, Ossolineum, Wrocław.

Prus Bolesław [właśc. Głowacki Aleksander] (2010), Literackie notatki o kompozycji, wstęp, wybór i opracowanie Anna Martuszewska, Słowo/obraz terytoria, Gdańsk.

Tomkowski Jan (1993), Mój pozytywizm, Wydawnictwo IBL PAN, Warszawa.

Żeleński (Boy) Tadeusz (1956), Pisma, t. 6: Szkice literackie, oprac. Henryk Markiewicz, pIw, Warszawa.

Żeromski Stefan (1962), Z „Dzienników”, w: Wspomnienia o Bolestawie Prusie, zebrał i oprac. Stanisław Fita, PIw, Warszawa, s. 128.

Wiesław Ratajczak

\section{On the need for faithfulness to details}

This article concerns the book Prus. Śledztwo biograficzne [Prus. A biographical investigation] by Monika Piątkowska, a new biography of the nineteenth-century writer that enjoys great readership. However, it contains many superficial interpretations and simplifying applications. Piątkowska argues that in his stories and novels, Bolesław Prus included many autobiographical elements. This interpretation key fails. The schematic depiction of the psychological layer of literary works, the lack of references to previous studies of the work and life of Prus, disregarding the intellectual dimension of his biography - these are the most significant drawbacks of this book. The author of the review shows examples of the researcher's simplifications and lack of competence.

Keywords: biography; psychologism in literary studies; Bolesław Prus; novel of the nineteenth century. 
Wiesław Ratajczak - doktor habilitowany, historyk literatury. Zajmuje się literaturą i kulturą polską 2. połowy XIX wieku. Autor książek: Teodor Tomasz Jeż (Zygmunt Miłkowski) i wiek XIx (2006), Stownik motywów literackich (2006), Literatura polska XIX wieku (2008), Conrad i koniec epoki żaglowców (2010), „Stąd konserwatyzm jest pozytywizmem”. Myśl społeczno-polityczna młodych konserwatystów warszawskich i ich adherentów 1876-1918 (wspólnie z Maciejem Glogerem; 2018), Spór o Conrada 1945-1948 (2018). Współredaktor licznych tomów zbiorowych, m.in.: Europejskość i rodzimość. Horyzonty twórczości Józefa Ignacego Kraszewskiego (2006), Norwid - artysta (2010), W kręgu mtodokonserwatyzmu warszawskiego 1876-196 (2015), Krasiński i Kraszewski wobec europejskiego romantyzmu i dylematów XIX wieku. $W d$ wustulecie urodzin pisarzy (2016). 